\title{
ON THE OCCURRENCE OF HYDROMERMIS CONTORTA (KOHN) (NEMATODEA) PARASITIZING MIDGES (CHIRONOMIDAE) IN THE CAMARGUE
}

\author{
par George O. Poinar, Jr. ${ }^{1}$ and J. N. Toureng ${ }^{2}$.
}

\section{Introduction.}

The nematode, Hydromermis contorta (Kohn) of the family Mermithidae, has been found parasitizing members of the Chironomidae in Europe and America (see TABLE 1).

During the spring of 1971 , larval chironomid populations were sampled at various localities in the Camargue to search for natural parasites. This was one aspect of a general ecological study on chironomid populations in the Camargue currently being conducted by the junior author. One population was found parasitized by Hydromermis contorta (Kohn). The parasites were found in Chironomus annularius (Mg.) and C.dorsalis (Mg.), thus establishing 2 new host records for this mermithid (Fig. $1 \mathrm{~A}$ ).

TABLE I. - List of hosts for Hydromermis contorta (Kohn).

\begin{tabular}{|c|c|c|}
\hline Host species & Locality & Reference \\
\hline Chironomus annularius (Mg.) & France & $\begin{array}{l}\text { Poinar and Tourenq (present } \\
\text { study) }\end{array}$ \\
\hline Chironomus dorsalis (Mg.) & France & $\begin{array}{l}\text { Poinar and Toureng (present } \\
\text { study) }\end{array}$ \\
\hline Chironomus plumosus L. & Germany & Köhn, 1905 \\
\hline Chironomus plumosus L. & America & Johnson, 1955 \\
\hline Chironomus plumosus $\mathrm{L}$. & France & $\begin{array}{l}\text { Poinar and Tourenq (present } \\
\text { study) }\end{array}$ \\
\hline Chironomus tentans Fabr. & Italy & Parenti, 1962 \\
\hline Chironomus thummi K. & France & Comas, 1927 \\
\hline Tanytarsus gregarius (K.) & Germany & Wülker, 1961 \\
\hline
\end{tabular}

1. Division of Entomology and Parasitology, University of California, Berkeley, California 94720.

2. Laboratoire d'Hydrobiologie, Université Paul-Sabatier, 118, route de Narbonne, 31-Toulouse. 


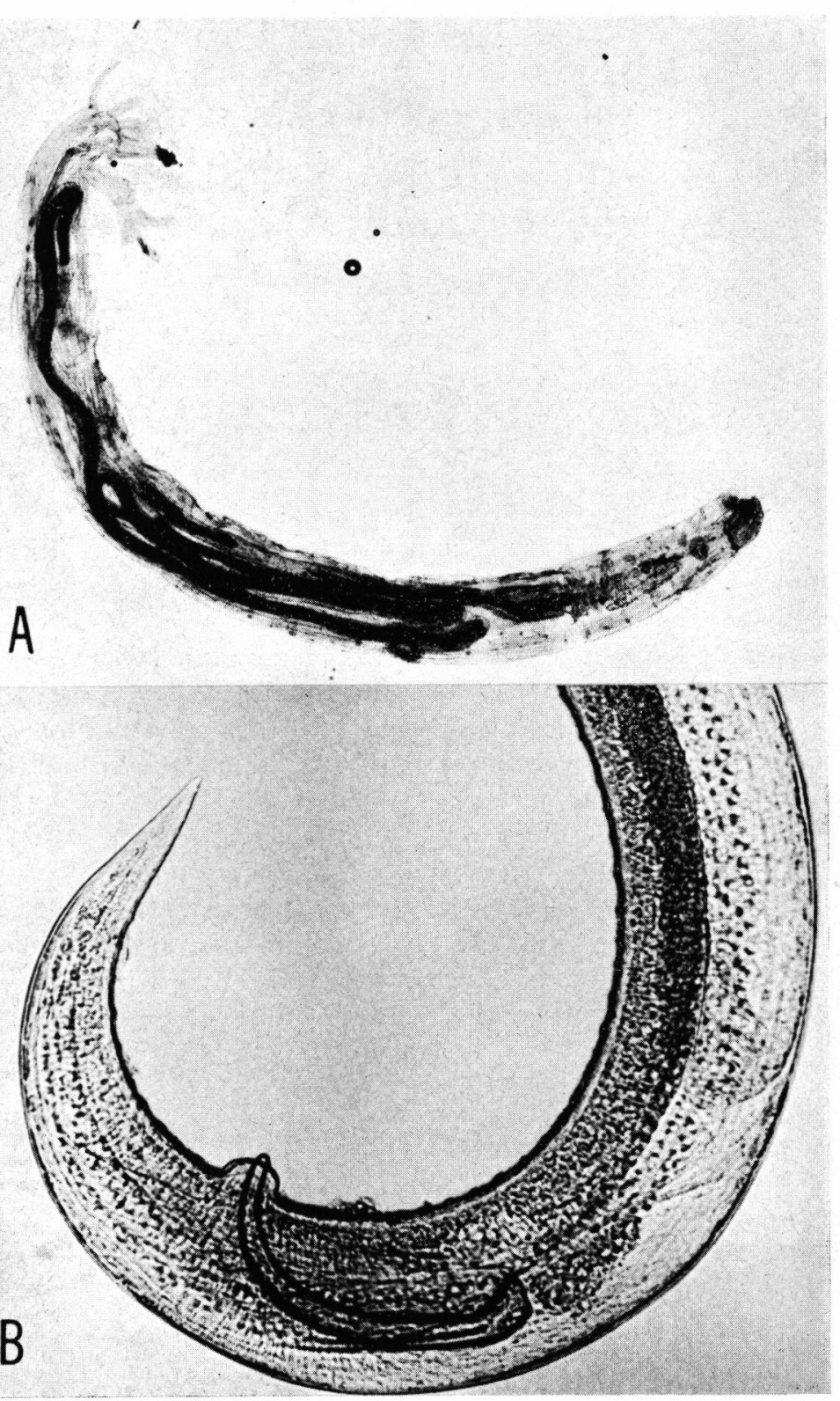

FIG. 1. - A : Hydromermis contorta (Kohn) within the last instar larva of Chironomus annularius $(X 11,4)$. - B : Detail of the tail end of a male of Hydromermis contorta (Kohn) showing the $\mathrm{C}-$ curved spiculum ( $\times 125)$ 
The present paper presents data on the occurrence and seasonal distribution of $H$. contorta and discusses aspects of its morphology and variation in comparison with previous reports.

\section{Materials and Methods.}

Chironomids from nematode-infested areas were collected from irrigation and evacuation canals at the Tour du Valat, in the Camargue from April to July, 1971. The water was aliways fresh, permanent and lightly flowing. The chlorosity varied from 0 to 0.2 grams of chloride ions/liter. The water temperature remained fairly constant, varying from $17^{\circ} \mathrm{C}$ in April to $24^{\circ} \mathrm{C}$ in July. The $\mathrm{pH}$ varied from 7 to 7.6 during the same period. The water was relatively poor in dissolved oxygen, containing from 7 ppm (parts per million) in April to $4 \mathrm{ppm}$ in June (WinkLer method) (saturation $40 \rightarrow 70 \%$ ). The total carbon dioxide content (measured with the VAN SLYKE method) showed a value between 100 and $200 \mathrm{mgr} / \mathrm{liter}$.

Chironomid larvae were sampled by draggind a net over the bottom of the canals, which were approximately 1 meter deep. The collected larvae were separated into the taxonomic groups, Chirinominae and the Tanypodinae :

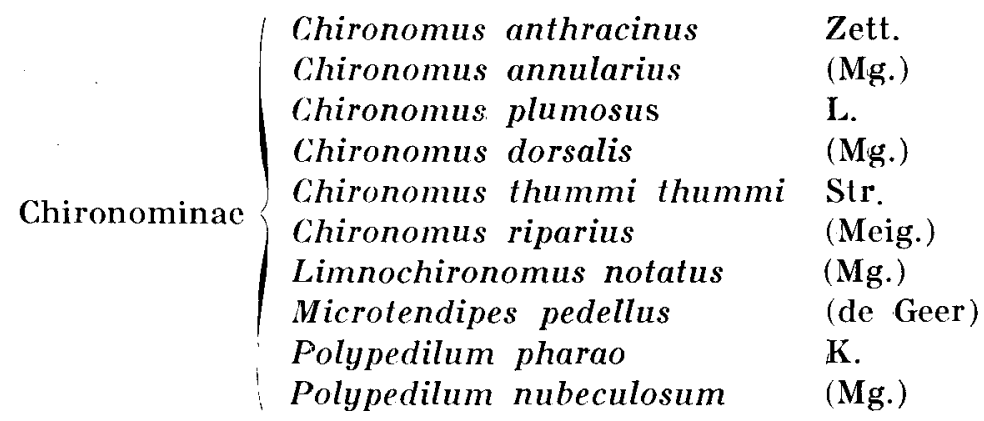

Those making up the latter group were :

Tanypodinae $\begin{cases}\text { Procladius culiciformis } & \text { (Mg.) } \\ \text { Tanypus punctipennis } & \text { (Meig.) } \\ \text { Psectrotanypus varius } & \text { (Fabr.) }\end{cases}$

The above species were recovered from the collecting site at each sampling period. In the laboratory, the larvae were 'washed and placed in large pans for observation. The parasitized forms were removed and held in smaller dishes until the nematodes emerged. For morphological studies, the nematodes were killed with gentle heat, fixed in $3 \%$ formalin and processed to glycerin. 


\section{Results.}

The results of sampling populations of Chironomidae for the presence of $H$. contorta from April to July of 1971 are given in Table II. Throughout the experimental period, $H$. contorta was found only parasitizing the larvae of $C$. annularius $\mathrm{Mg}$., C. dorsalis Mg. and C. plumosus $L$.

TABLE II. - Results of sampling populations of Chironomidae for the presence of Hydromermis contorta (Kohn) during the spring of 1971 in the Camargue.

\begin{tabular}{|c|c|c|c|c|c|c|}
\hline \multirow[b]{2}{*}{ Date } & \multicolumn{2}{|c|}{ Chironominae } & \multicolumn{4}{|c|}{ Tanypodinae } \\
\hline & $\begin{array}{c}\text { No. } \\
\text { examined }\end{array}$ & $\begin{array}{c}\text { No. } \\
\text { parasitized }\end{array}$ & $(\%)$ & $\begin{array}{c}\text { No. } \\
\text { examined }\end{array}$ & $\begin{array}{c}\text { No. } \\
\text { parasitized }\end{array}$ & $(\%)$ \\
\hline April 2 & 100 & 46 & (46) & 16 & 0 & $(-)$ \\
\hline April 23 & 174 & 56 & (32) & 11 & 0 & (-) \\
\hline May 17 & 451 & 21 & (5) & - & - & \\
\hline June 1 & 380 & 0 & $(-)$ & 一 & - & \\
\hline July & 205 & 1 & $(0.5)$ & 123 & 0 & $(-)$ \\
\hline July & 206 & 0 & $(-)$ & 120 & 0 & $(-)$ \\
\hline July 10 & 518 & 0 & $(-)$ & 162 & 0 & $(-)$ \\
\hline July 30 & 223 & 0 & $(-)$ & 103 & 0 & $(-)$ \\
\hline
\end{tabular}

The percentage of parasitism was heaviest in the beginning of April and then dropped off rapidly toward the middle of May. Although the hosts were present in June and July, the parasitized chironomids were very rare.

When kept at $20^{\circ} \mathrm{C}$, the mermithids emerged the day after collecting the parasitized larvae and began mating at once. In contrast to the terrestrial mermithids, the eggs for $H$. contorta were fully formed upon emengence from the host and oviposition commenced from 1-3 days after emergence. An unusual feature of $H$. contorta is that the adult nematodes emerge from the host, having completed their last molt in the chironomid. In contrast, all other mermithids have one or 2 molts after leaving their host. Perhaps this feature can serve as a diagnostic character. The preparasitic juveniles emerged from the eggs 7-10 days after oviposition and some remained alive under refrigeration $\left(5^{\circ} \mathrm{C}\right)$ for 66 days. Attempts at infecting larvae of Aedes aegypti with the infective stages of $H$. contorta were unsuccessful.

A description of the specimens of $H$. contorta taken from Chironomus annularius follows: The first figure following the character is the average value of observations made and those in parenthesis represent the range. All measurements are in millimeters. 
Hydromermis contorta (Kohn).

Adult : Containing the diagnostic characters of the genue Hydromermis, namely, 6 head papillae, 8 hypodermal chords at midbody, cuticle lacking cross fibers, an S-shaped vagina and a short single spicule in the male.

Female : $(\mathrm{n}=10)$ Length $38.1(31.1-54.8)$; width $.20(.20-.34)$; diameter of head $.07(.06-.09)$; head to nerve ring $.26(.23-.29)$; length amphid .012 (.009-.013); head to tịp of amphid .021 (.015$.026)$; diameter of amphidial opening .006 (.004-.009); length of vagina .46 (.36-.58); \% vulva (39-49); egg diameter (in uterus) .052 (.046-065). Tail pointed.

Male : $(\mathrm{n}-10)$ Length 23.1 (14.4-30.5); width .17 (.14-.20); diameter of head .07 (.06-.09); head to nerve ring .23 (.19-.27); length amphid .014 (.013-.016); head to tip of amphid .022 (.013$0.30)$; diameter of amphidial opening .008 (.006-.010; length of spicule $.29(.20-.39)$; length of anus .35 (.31-.47). Spicule with a characleristic bend and containing minute protuberances on the lip (Fig. 1 B). Tail with 3 broken rows of genital papillae, ranging from 30-50 in each pre anal row and 10-20 in the post anal rows. These papillae often extend to just behind the tip the tail terminus. Tail sharply pointed.

Infective stage juveniles $:(\mathrm{n}=10)$ Length .58 (.54-.61); width $.013(.012-.015)$. L.

Hosts : Chironomus annularius Mg., C. dorsalis Mg., C. plumosus

Locality : Irrigation and evacuation canals, 'Tour du Valat, Camargue.

Variation : A comparison of the quantitative values of Hydromermis contorta (Kohn) from 4 seperate studies is shown in Table III. It is interesting to see that although the values vary slightly, the figures given for the range of most characters overlap, thus indicating that $H$. contorta appears to be a fairly stable species. Even in America, 'where Jousson (1955) found the nematodes generally larger, there is still an overlap in size with European material.

JoHnson (1955) also felt that the European form had a blunter head than the American contortus, basing his conclusions on the drawings of HAGMEIER (1912). However from the present material, it appears that the curvature of the head is a variable character and no definite conclusions based on geographical separation can be drawn. Other characters noted here were the presence of numerous anal papillae and small denticles on the tip of the spicule, in contrast to the 4 teeth shown for $H$. contorta by HaGMEIER (1912). 
TABLE III. - Measurements of Hydromermis contorta (Kohn) from various localities (all in $\mathrm{mm}$ ).

\begin{tabular}{|c|c|c|c|c|}
\hline Character & $\begin{array}{l}\text { KOHN } \\
(1905)\end{array}$ & $\begin{array}{l}\text { HAGMEIER } \\
(1912)\end{array}$ & $\begin{array}{l}\text { JOHNSON } \\
(1955)\end{array}$ & Present study \\
\hline length - female & $26-50$ & $19-40$ & $50(23-70)$ & $38 \quad(31-54)$ \\
\hline - male & $13-26$ & $14-25$ & $26(15-40)$ & $23(14-30)$ \\
\hline width - female & $.18-.37$ & $.18-.24$ & $.31(.22-.44)$ & $.27(.20-.34)$ \\
\hline head diameter & $.07-.21$ & $.13-.19$ & $.24(.12-.33)$ & $.17(.14-.20)$ \\
\hline - female & - & $.053-.075$ & $.066(.051-.087)$ & $.072(.068-.090)$ \\
\hline - male & 一 & $.062-.075$ & $.054(.041-.071)$ & $.071(.061-.085)$ \\
\hline $\begin{array}{l}\text { - female } \\
\text { male }\end{array}$ & - & $.198-.260$ & $.270(.212-.358)$ & $\begin{array}{l}.259 \\
230\end{array}(.231-.285)$ \\
\hline length vagina & .50 & - & $\begin{array}{r}222(.161 \\
.50\end{array}$ & $.46(.39-.59)$ \\
\hline$\%$ Vulva & - & - & $45 \quad(32-50)$ & $45(39-49)$ \\
\hline egg diameter & $.053-.068$ & .060 & .060 & $.053(.047-.065)$ \\
\hline length spicule & .20 & $.20-.30$ & $.314(.235-.472)$ & $.29(.20-.39)$ \\
\hline length male tail & 一 & $.185-.264$ & $.348 \quad(.170-.447)$ & $.354(.308-.470)$ \\
\hline $\begin{array}{l}\text { length infective } \\
\text { stage } \\
\text { width infective }\end{array}$ & $\therefore$ & 88 & 7 & $.58(.54-.61)$ \\
\hline stage & $.003-.012$ & .013 & .012 & $.013(.012-.015)$ \\
\hline
\end{tabular}

These findings agree with Johnson's description of the American H. contortus.

It should also be noted that there has been some confusion regarding the taxon Hydromermis contorta in the literature since there are 2 species of nematodes known by this name. Von LinsTow (1889) described $H$. contorta from samples of mermithids he found in mud. Although his samples were not adequate, he could determine that cross-fibers were present and there were 6 hypodermal chords, characters which are found in the genus Paramermis. Кон (1905) described his $H$. contorta he collected from C. plumosus as lacking cross fibers and having 8 hypodermal chords, characters belonging to the genus Hydrodermis. Although both von Linstow and KoHs might have felt they were dealing with the same worm, it is now obvious that they were working with different species. In this paper, all discussion pertains to KoHN's Hydromermis contorta which has been re-discovered since by various authors.

\section{Discussion.}

Finding $H$. contorta $(\mathrm{Kohn})$ only in 3 host species in the areas sampled, although there were many other chironomid larvae in 
the same habitat, suggests that host specificity exists in the ability of $H$. contorta to parasitize members of this group.

Many samples of chironomids (Chironomus sp., Cricotopus sp.) were taken from aquatic habitats in the Camargue varying in salt concentration from zero to very salty, however mermithids were only found parasitizing midges in fresh water. As for $H$. contorta, its limited distribution might depend on the concentrated supply of a suitable host as well as the lack of salinity of the water. Mermithids occurring in brackish or salt water are uncommon and thus far, Agamomermis culicis, a parasite of the mosquito, Aedes sollicitans, is the only nematode known to us that is capable of surviving in salty water. It would be interesting to determine if salt tolerance by mermithid nemalodes is really as rare as it seems and if they can be encouraged to adjust to living in water with low salt concentrations.

The high percentage of parasitism observed on April 2 indicates that $H$. contorta is an important factor limiting chironomid populations at certain periods in the year.

The presence of the nematodes is undoubtedly connected with the host's life cycle, and there is probably a synchronization between the emergence of the infective stage nematode and the presence of young second or third instar chironomid larvae. Although our results indicate a single generation each year, more samples should be taken since JoHsson (1955) found a peak of C. plumosus larvae attacked by $H$. contorta in November and again in March and April in Indiana and concluded that there are 2 parasitic generations per year. How this is accomplished when it is agreed that $C$. plumosus has only a single generation per year is not known.

\section{SUMMARY}

Hydromermis contorta (Kohn) (Mermithidae: Nematodea) was found parasitizing Chironomus annularius $\mathrm{Mg}, C$. dorsalis $\mathrm{Mg}$ and C. plumosus $\mathrm{L}$. in the Camargue. The first 2 species are new host records for this mermithid nematode. The percentage of parasitism was followed from April to July, 1971 and reached $46(n=100)$ early in April. The morphology of the adlult nematodes was studied and quantitative measurements were made and compared with those reported by earlier authors. These parasites may serve as an important controlling agent of chironomids in certain areas in the Camargue.

\section{SUR LA PRESENCE DE HYDROMERMIS CONTORTA (KOHN) PARASITE DES LARVES DE CHIRONOMIDES DE CAMARGUE.}

En Camargue les larves de Chironomus annularius Mg, Chironomus dorsalis $\mathrm{Mg}$ et Chironomus plumosus L. sont parasitées par Hydromermis contorta (Kohn) (Mermithidae: Nematodea). Les larves de Chironomus 
annularius et $C$. dorsalis sont des hôtes nouveaux pour ce mermithide parasite. Le pourcentage des larves parasitées a été suivi d'avril à juillet 1971; dès avril le pourcentage atteignait $46 \%$. La morphologie du nématode adulte est étudiée, les mesures effectuées sont comparées avec celles trouvées par les auteurs ayant déjà décrit cette espèce. Ces parasites pourraient servir à contrôler l'effectif des Chironomides dans certaines zones de la Camargue.

\section{UBER DAS VORKOMMEN DES PARASITEN HYDROMERMIS CONTORTA (KOHN) (NEMATODEA) IN DEN CHIRONOMIDEN-LARVEN IN DER CAMARGUE}

In der Camargue ist der Parasite Hydromermis contorta (Kohn) (Mermithidae : Nematodea) auf den Larven folgender Chironomiden gefunden worden : Ch. annularius (Mg), Ch. dorsalis (Mg), Ch. plumosus (L.).

Die Larven der $C h$. annularius und $C h$. dorsalis sind neu als Parasitenträger dieses Mermithiden.

Der Prozentsatz der erkrankten Larven, die vom April bis Juli 1971 erfasst worden sind, betrug schon im April $46 \%$.

Dic Morphologie des ausgewachsenen Nemathoden ist untersucht worden. Die ausgeführten Messungen wurden mit denjenigen verglichen, die schon von andern Autoren über die gleiche Art vorliegen.

Dieser Parasite könnte zur Kontrolle des Chironomidenbestandes in gewissen Gebieten der Camargue dienen.

\section{LITERATURE CITED}

Comas (M.). 1927. - Sur le mode de pénétration de Paramermis contorta v. Linst. dans la larve de Chironomus thummi Kief. Compt. Rend. Soc. Biol. Paris, 96: 673-675.

Hagmeier (A.). 1912. - Beiträge zur Kenntnis der Mermithiden. Zool. Jahrb. (Syst)., 32 : 521-612.

JoHnson (A. A.). 1955. -- Life history studies on Hydromermis contorta (Kohn), a nematode parasite of Chironomus plumosus (L.), Ph. D. thesis-University of Illinois, $93 \mathrm{p}$.

Koнn (F. G.). 1905. - Einiges über Paramermis contorta (v. Linst.) = Mermis contorta Linst. Arb. a. d. Zool. Inst. d. Univers. Wein., 15 : 213-256.

Parenti (U.). 1962. - Fecondazione e corredo cromosomico di Paramermis conlorta parassita de Chironomus tentans. Rend. Classe di Scienze fisiche, matematiche e naturali, 32 : 699-702.

Von Linstow (O. F.). 1889. - Bemerkungen über Mermis. Arch. Mikr. Anat., 34 : 390-396.

WüLKER (W.). 1961. - Untersuchungen über die Intersexualität der Chironomiden (Dipt.) nach Paramermis - Infektion. Arch. Hydrobiol., Suppl. 25 : 127-181. 